\title{
Targeting the UPS as Therapy in Multiple Myeloma
}

\section{Citation}

Chauhan, Dharminder, Giada Bianchi, and Kenneth C. Anderson. 2008. Targeting the UPS as therapy in multiple myeloma. BMC Biochemistry 9(Suppl 1): S1.

\section{Published Version}

doi:10.1186/1471-2091-9-S1-S1

\section{Permanent link}

http://nrs.harvard.edu/urn-3:HUL.InstRepos:8231689

\section{Terms of Use}

This article was downloaded from Harvard University's DASH repository, and is made available under the terms and conditions applicable to Other Posted Material, as set forth at http:// nrs.harvard.edu/urn-3:HUL.InstRepos:dash.current.terms-of-use\#LAA

\section{Share Your Story}

The Harvard community has made this article openly available.

Please share how this access benefits you. Submit a story.

\section{Accessibility}




\title{
Targeting the UPS as therapy in multiple myeloma Dharminder Chauhan*, Giada Bianchi and Kenneth C Anderson
}

Address: The Jerome Lipper Multiple Myeloma Center, Department of Medical Oncology, Dana Farber Cancer Institute, Harvard Medical School, Boston, MA 02115, USA

Email: Dharminder Chauhan* - Dharminder_Chauhan@dfci.harvard.edu; Kenneth C Anderson - kenneth_anderson@dfci.harvard.edu

* Corresponding author

Published: 21 October 2008

BMC Biochemistry 2008, 9(SuppI I):SI doi:I0.II86/I47I-209I-9-SI-SI

This article is available from: http://www.biomedcentral.com/|47I-209I/9/SI/SI

(C) 2008 Chauhan et al; licensee BioMed Central Ltd.

This is an open access article distributed under the terms of the Creative Commons Attribution License (http://creativecommons.org/licenses/by/2.0), which permits unrestricted use, distribution, and reproduction in any medium, provided the original work is properly cited.

\begin{abstract}
: The coordinated regulation of cellular protein synthesis and degradation is essential for normal cellular functioning. The ubiquitin proteasome system mediates the intracellular protein degradation that is required for normal cellular homeostasis. The $26 \mathrm{~S}$ proteasome is a multienzyme protease that degrades redundant proteins; conversely, inhibition of proteasomal degradation results in intracellular aggregation of unwanted proteins and cell death. This observation led to the development of proteasome inhibitors as therapeutics for use in cancer. The clinical applicability of targeting proteasomes is exemplified by the recent FDA approval of the first proteasome inhibitor, bortezomib, for the treatment of relapsed/refractory multiple myeloma. Although bortezomib represents a major advance in the treatment of this disease, it can be associated with toxicity and the development of drug resistance. Importantly, extensive preclinical studies suggest that combination therapies can both circumvent drug resistance and reduce toxicity. In addition, promising novel proteasome inhibitors, which are distinct from bortezomib, and exhibit equipotent anti-multiple myeloma activities, are undergoing clinical evaluation in order to improve patient outcome in multiple myeloma.
\end{abstract}

Publication history: Republished from Current BioData's Targeted Proteins database (TPdb; http://www.targetedproteinsdb.com).

\section{Protein pathway involvement in disease \\ The ubiquitin proteasome system (UPS)}

Intracellular protein degradation occurs primarily through a multisubunit complex called the proteasome [1-3]. Pioneering studies by Ciechanover et al. showed that ATP-dependent conjugation of proteins with a polypeptide, ubiquitin (UBIQ), is required for protein degradation [4-7]. Subsequent reports demonstrated the role of UBIQ in cellular protein turnover $[8,9]$, and it is now well established that ubiquitylation of proteins accounts for their stability, functionality, localization and interactive capabilities [10].
UBIQ-mediated proteolysis occurs via the $26 \mathrm{~S}$ proteasome complex [11-15], which contains 19S units flanking a barrel-shaped 20S proteasome core [16,17]; the 19S units regulate entry of ubiquitylated proteins into the $20 \mathrm{~S}$ core chamber $[2,18,19]$. Protein breakdown involves sequential enzymatic reactions that culminate in target proteins becoming linked to a chain of UBIQ molecules. In the first reaction, the E1 ubiquitin enzyme activates UBIQ and attaches it to the ubiquitin-conjugating enzyme E2 in an ATP-dependent manner. The E3 ubiquitin ligase then links the UBIQ molecule to the target protein or to a previously attached UBIQ moiety [20]. Sequential cycles of this process lead to the formation of polyubiquitylated 
proteins that are eventually degraded by the proteasomes into small peptides, with re-cycling of free UBIQ [21-24]. Importantly, E3 ubiquitin ligases confer specificity in the UBIQ signaling pathway by selectively targeting potential protein substrates for ubiquitylation and subsequent proteasomal degradation [25]. Three proteasomal activities that regulate proteolysis are chymotrypsin-like (CT-L), trypsin-like (T-L) and caspase-like (C-L), also known as $\beta 5, \beta 2$ and $\beta 1$, respectively; all of these reside within the 20S proteasome core [26-28].

Proteolysis is a normal cellular process and thus substrates for proteasomes include many cellular proteins that maintain normal cell cycle progression, growth and survival [1,2,8,29-31]. Conversely, pharmacological inhibition of proteasome function hampers the normal elimination of misfolded proteins, thereby causing a build-up of unwanted proteins and eventual cell death [32-34]. These laboratory observations have translated into the clinical application of proteasome inhibitors as anticancer therapies. However, since the proteasome regulates normal cellular functions, its inhibition could also trigger toxicity against normal cells $[33,35,36]$. Importantly, recent studies have shown that proteasome inhibitors are more cytotoxic to proliferating malignant cells than quiescent normal cells, suggesting a favorable therapeutic index [3541].

\section{Targeting the UPS in multiple myeloma}

As stated in the section The ubiquitin proteasome system (UPS), a broad spectrum of intracellular proteins are substrates for proteasome-mediated degradation. This process involves $\mathrm{NF \kappa B}$, a transcription factor that plays a pivotal role in the inflammatory response and carcinogenesis by controlling genes involved in growth, survival, cell cycle progression, angiogenesis and invasion [42-44]. Palombella et al. showed that the UPS is required for processing the NFKB1 (NFKB1) precursor protein and for activation of NFKB [45]. Conversely, inhibition of proteasomes by proteasome inhibitor MG132 blocked NFkB activity [46]. Importantly, our studies showed that adhesion of MM cells to bone marrow stromal cells (BMSCs) triggered transcription and secretion of various cytokines that confer growth, survival and drug resistance in $\mathrm{MM}$ cells $[47,48]$. Other studies further confirmed the role of $\mathrm{NF \kappa B}$ as a major growth and survival signaling pathway in MM [49-53]. The survival- and growth-promoting role of $\mathrm{NF \kappa B}$ in $\mathrm{MM}$, together with the ability of proteasome inhibitors to block NFkB, provided the initial rationale for proteasome inhibitor therapy in MM. Studies by Palombella et al. focused on the development of a series of peptide boronic acid inhibitors of the proteasome, in particular bortezomib, and demonstrated their inhibitory activity on NFKB [46]. The dipeptidyl boronic acid bortezomib is a potent and reversible inhibitor of the CT-L activity of the proteasome [33,41]. Initial NCI screening showed the remarkable antitumor activity of bortezomib against a panel of 60 tumor cell lines [41,54]. Our in vitro studies showed that bortezomib downregulates NFKB, blocks constitutive and $\mathrm{MM}$ cell adhesion-induced cytokine secretion in BMSCs and induces apoptosis in both MM cell lines and freshly isolated MM cells from patients [35,51]. Moreover, in vivo studies using animal models (see Disease models, knockouts, assays) demonstrated a potent anti-MM activity of bortezomib $[36,55]$.

\section{Disease models, knockouts, assays}

Our in vitro findings have also been validated in vivo using animal models. These models represent an indispensable bridge between basic research and clinical drug development and have been extensively used in the validation of bortezomib and other novel compounds against MM [5557]. One of the first models to be used was the human plasmacytoma xenograft model, in which triple immunodeficient mice (beige-nude-xid) were injected subcutaneously with MM cells [55]. This model allows us to simultaneously measure the effect of in vivo drug treatment on the growth of human MM cells (assessed by tumor cell size, human idiotypic protein in mouse serum and host survival), as well as the neighboring blood vessels (assessed by microvessel density). Our studies using this model showed that bortezomib inhibits both human MM cell growth and associated angiogenesis in vivo [55].

Although the human plasmacytoma xenograft model allows for direct assessment of therapy of tumor growth and associated angiogenesis, it does not reflect the bone marrow milieu. For these studies, we have utilized the SCID-hu mouse model developed in our laboratory [58]. This model examines MM cell growth in the human bone marrow milieu, which includes human BMSCs, extracellular matrix proteins and cytokines, and best reflects the human disease [58-60]. In this model, MM cells are injected directly into human fetal bone chips implanted subcutaneously in SCID mice. Tumor growth is assessed by evaluating circulating levels of soluble human IL6R and human monoclonal antibody levels using ELISA [57]. This model allows us to perform immunohistochemical analysis of excised human bone chips in order to determine MM cell growth in vivo using staining with antibodies specific for tumor cells (SYND1 [CD138]). Immunohistochemical analysis of human bone sections from mice treated with various drugs, such as bortezomib, lenalidomide or NPI-0052, can be performed to detect apoptosis (CASP3 [caspase-3] activity, TUNEL staining), growth inhibition (Ki67) and angiogenesis (PECA1 [CD31] and FA8 [Factor VIII staining]). ELISA and human cytokine bead arrays are utilized for analyzing the effect of drugs on human cytokine secretion in mouse serum triggered by human MM-BMSC interactions. This model 
therefore permits the evaluation of the molecular and cellular changes induced by human MM-human stroma interactions in vivo, before and after therapy. We have used this model to validate novel targeted therapies such as CD-138-DM1 antibody [57] and BAFF inhibitor [61]. Our ongoing studies are examining the effects of various proteasome inhibitors in this model.

Validation of the proteasome as a target for antineoplastic therapy has led to the development of assays that not only quantify the bulk of the proteasomes in cells, but also qualitatively assess their function $[3,28]$. Given the differential proteolytic activities of the proteasome and the growing number of available inhibitors, it is essential to establish a relationship between the effectiveness of the drugs and the extent and type of proteasomal blockade. Fluorogenic peptide substrates specific for each proteasomal subunit provide a rapid, sensitive and accurate tool for assessing residual proteasomal activity in crude lysates [62]. Although extremely useful, these probes require prior cell lysis, thus isolating the proteasome from its functional, regulatory environment [63]. Moreover, fluorogenic substrates do not differentiate between constitutive and interferon-inducible (immunoproteasome) proteasomal activities [63]. These limitations have aroused interest in designing cell permeable, specific proteasome probes, such as DansylAhx ${ }_{3} \mathrm{~L}_{3} \mathrm{VS}$, capable of monitoring proteasome activity in living cells [64]. DansylAhx $\mathrm{L}_{3} \mathrm{~V}$ VS has been proven to be useful for defining the differential activity profiles of the two proteasome inhibitors bortezomib and NPI0052 in MM cell lines [36]. It was also effective in differentiating between the inhibition of constitutive and inducible proteasomal activity in peripheral blood mononuclear cells from patients undergoing treatment with bortezomib [65]. These experiments confirm the use of DansylAhx $\mathrm{L}_{3} \mathrm{VS}$ for quantitatively and qualitatively monitoring proteasomal blockade in patients receiving proteasome inhibitor therapy [65].

\section{Disease targets and ligands}

Preclinical studies provided the basis for the evaluation of bortezomib as a therapy in MM. A Phase I clinical trial on 27 patients with refractory hematologic malignancies showed anti-MM activity and acceptable toxicity, and in a Phase II trial enrolling 202 relapsed, refractory MM patients, one third of the patients achieved durable responses (with $4 \%$ complete responses) and associated clinical benefit. This provided the basis for accelerated FDA approval of bortezomib treatment for relapsed refractory MM $[66,67]$. Thereafter, a randomized Phase III trial on $669 \mathrm{MM}$ patients who had relapsed after at least one prior treatment showed higher responses, as well as prolonged time to progression and survival, after treatment with bortezomib when compared with dexamethasone [68]. This provided the basis for the extension of
FDA approval of bortezomib to include treatment of relapsed MM. Despite the success of bortezomib therapy ( $43 \%$ objective response rates), it has been associated with possible off-target toxicities and the development of drug resistance $[67,69-72]$. Therefore, extensive laboratory efforts are now focused on delineating the molecular mechanisms mediating bortezomib cytotoxicity and drug resistance, in order to both enhance sensitivity and overcome clinical resistance to bortezomib.

\section{Mechanistic insights into bortezomib-induced cell death}

Bortezomib-triggered apoptosis in MM cells is associated with inhibition of NFKB; however, whether NFkB blockade is an obligatory event remains unclear. To address this issue, we compared the effects of PS1145, a specific inhibitor of IKKB (IKK-B), with the effects of bortezomib on $\mathrm{NF \kappa B}$ and consequent biological response (cell death) in MM cells. Both PS1145 and bortezomib block TNFA (TNF- $\alpha$ )-induced NFKB activation by inhibiting phosphorylation and degradation of IKKB. However, in contrast to bortezomib, PS1145 only partially inhibits MM cell growth [50]. These findings showed that NFKB inhibition alone is unlikely to account for the overall anti-MM activity of bortezomib. Supportive of these findings, studies to date suggest that bortezomib affects both growth and apoptotic signaling pathways. For example, bortezomibtriggered apoptosis is associated with: activation of heat shock proteins (HSPB1 [Hsp27], Hsp70 and Hsp90) $[73,74]$; upregulation of JNK/SAPK $[73,75,76]$; generation of reactive oxygen species [77]; release of CYC (cytochrome-c)/DBLOH (Smac) from mitochondria into the cytosol and activation of CASP9 (caspase-9) and CASP3 (caspase-3) $[75,76]$; activation of BIM (Bim) and CASP8 (caspase-8) [73,76]; blockade of DNA repair [78]; inhibition of MM-BMSC interactions and sequelae including activation of MAPK and PI3K signaling pathways [35,79], and induction of ER stress and an unfolded protein response [80,81]. Together, these in vitro studies suggest that proteasome inhibition by bortezomib triggers both various apoptotic signaling cascades and blocks growth/ survival mechanisms in MM cells [82].

\section{New frontiers in drug discovery}

Oncogenomics and proteomic studies in $\mathrm{MM}$ cells are identifying and validating key molecules, the pharmacological inhibition of which enhances the antitumor activity of bortezomib and could abrogate drug resistance [83]. Firstly, bortezomib induces Hsp90 in MM cells, whereas blockade of Hsp90 with 17AAG (Kosan Biosciences, USA) enhances sensitivity and even overcomes resistance to bortezomib [84]. Ongoing clinical trials show that combination therapy can achieve responses in refractory $\mathrm{MM}$ [85]. Secondly, laboratory studies show that bortezomib induces HSPB1 (Hsp27), and MM cells from patients resistant to bortezomib overexpress HSPB1 [74,86]. These 
findings have already been tested in a clinical trial by combining bortezomib with a p38 MAPK inhibitor, SCIOS469 (Scios USA), which downregulates HSPB1 and overcomes bortezomib resistance $[87,88]$. Thirdly, treatment of MM cell lines and SYND1 (CD138)+ MM cells with bortezomib and the novel agents lenalidomide (immunomodulatory agent from Celgene, USA) or CDDO-Imidazolide (a triterpenoid initially synthesized by Honda et al., Dartmouth College, USA) induces synergistic anti-MM activity in vitro and overcomes resistance to bortezomib by targeting both intrinsic and extrinsic apoptotic signaling. This was evidenced by the disruption of mitochondrial potential and cleavage of CASP9 (caspase9) and CASP8 (caspase-8) [89,90]. These in vitro studies provide the basis for clinical protocols combining these agents [91]. Fourth, bortezomib combined with conventional anti-MM agents such as dexamethasone (Merck USA), doxorubicin (Pharmacia S.p.A, Italy), melphalan (GlaxoSmithKline, UK) or mitoxantrone (Lederle Parenterals, Puerto Rico) induces additive or synergistic antitumor activity in MM cell lines and freshly isolated SYND1+ MM cells, as measured by decreased cell viability in colorimetric assays (MTT assay) [78].

A recent randomized Phase III trial in 646 patients showed that treatment with pegylated doxorubicin and bortezomib achieved increased overall survival and extent of responses, as well as prolonged time to progression, compared with bortezomib alone. This provided the rationale for FDA approval of this combination for the treatment of relapsed MM $[92,93]$. Finally, our preclinical studies showed that the simultaneous targeting of lysosomal and proteasomal (non-lysosomal mechanism) protein degradation triggers synergistic anti-MM activity $[94,95]$. For example, HDAC6 (HDAC-6) is required for the chaperoning of ubiquitylated proteins for aggresomal degradation. Simultaneous inhibition of proteasomes and aggresomes with bortezomib and tubacin (HDAC6 inhibitor) induces synergistic cytotoxicity in MM cell lines and primary cells from MM patients [95]. A recent study in pancreatic cancer cells showed that bortezomib triggered the formation of aggresomes (aggregates of ubiquitin-conjugated proteins), which are cytoprotective, whereas their disruption by HDAC6 siRNA induced synergistic apoptosis [96]. These findings set the stage for the evaluation of combined treatment protocols of bortezomib with HDAC inhibitors in both hematologic malignancies and solid tumors. Our study has already validated the anti-MM activity of HDAC inhibitor LBH589 (Novartis Pharmaceuticals, USA) [97]; and a Phase I safety study of LBH589, given in combination with bortezomib, is ongoing in MM patients [98].

\section{Discovery and validation of novel proteasome inhibitors NPI0052 and PRI7I as therapy}

A recent study showed that a novel proteasome inhibitor, NPI0052 (salinosporamide A), is able to overcome bortezomib resistance in MM cells. NPI0052 is a small molecule derived from the fermentation of Salinospora, a marine gram-positive actinomycete $[36,99,100]$. NPI0052 is a nonpeptide proteasome inhibitor with structural similarity to omuralide. Omuralide is clasto-lactacystin beta-lactone and is the active form of a proteasome inhibitor, lactacystin [82]. Despite the structural similarity with omuralide, NPI0052 can be distinguished by the presence of a uniquely methylated C3 RING juncture, chlorinated alkyl group at C2 and a cyclohexene ring at C5 [82,99-101]. Initial screening of NPI0052 against the NCI panel of 60 tumor cell lines showed an $\mathrm{IC}_{50}$ of $<10 \mathrm{nM}$ in all cases. Importantly, NPI0052 similarly triggered apoptosis in purified tumor cells from several MM patients relapsing after prior therapies including bortezomib and thalidomide [36]. In vivo efficacy of NPI0052 was shown using a human plasmacytoma xenograft mouse model. Specifically, NPI0052 inhibited MM tumor growth and prolonged survival of these mice at concentrations that were well tolerated, without weight loss or neurological changes [36,55]. Another study showed that NPI0052 is a more effective inducer of apoptosis than bortezomib in lymphocytic leukemic cells [102].

Examination of signal transduction pathways in MM cells showed that: NPI0052 is a more potent inhibitor of NFKB and related cytokine transcription and secretion than bortezomib; NPI0052-induced MM cell death is predominantly mediated by CASP8 and bortezomib-induced apoptosis requires both CASP8 and CASP9 activation [36]. Moreover, NPI0052 and bortezomib differentially affect $20 \mathrm{~S}$ proteasomal activities; NPI0052 inhibits all three proteasomal activities, i.e. CT-L, T-L and C-L, whereas bortezomib blocks CT-L and C-L but not T-L activities [36]. A recent study showed that simultaneous inhibition of multiple proteasome activities is a prerequisite for significant (i.e. $>50 \%$ ) proteolysis [62]. Another study showed that $50 \%$ inhibition of CFTR degradation in reticulocyte extracts requires concurrent blockade of CT-L and C-L proteasome activities [103]. Whether blocking all three activities is therapeutically advantageous will be evaluated in clinical trials of NPI0052. Nonetheless, the mechanistic differences between NPI0052 and bortezomib, i.e. their differential effect on proteasome activities and their dependence on specific apoptotic signal transduction pathways, provides a rationale for combination proteasome inhibitor regimens to enhance MM cytotoxicity. Indeed, the combination of NPI0052 with bortezomib induces synergistic anti-MM activity, without significantly affecting the viability of normal lymphocytes [36]. Enhanced cytotoxicity of the combination regimen 
could be due to higher levels of proteasome inhibition with the two drug regimens and/or activation of differential apoptotic signaling pathways. Nevertheless, these preliminary studies set the stage for clinical trials of combined proteasome inhibitors to improve patient outcome in MM.

Finally, PR171 or carfilzomib (Proteolix, USA) is another novel proteasome inhibitor. PR171 [104-106] is an irreversible proteasome inhibitor, predominantly targeting CT-L activity and triggering potent antitumor activity $[104,105]$. A Phase I trial demonstrated tolerability and responses [107] and Phase II trails are ongoing in relapsed/refractory MM [108]. Laboratory studies are currently examining whether PR171 can be combined with bortezomib to induce synergistic cytotoxicity in MM cells.

\section{Conclusion}

Delineation of the molecular and cellular mechanisms of bortezomib-induced apoptosis $[79,109]$ has provided the rationale for combining bortezomib with conventional (dexamethasone, doxorubicin, melphalan) and novel (lenalidomide, HSP inhibitors, HDAC inhibitors) agents in order to reduce toxicity, enhance cytotoxicity and overcome drug resistance. Although bortezomib and NPI0052 belong to the same class of drugs, they are distinct in their mode of action and can be rationally combined as therapy $[36,102,110]$. The synergy observed in preliminary studies suggests an increased therapeutic index of combined therapy. However, more definitive evidence of enhanced efficacy of this combination regimen awaits careful clinical trials.

\section{List of abbreviations used}

BMSC: bone marrow stromal cell; C-L: caspase-like; CT-L: chymotrypsin-like; MM: multiple myeloma; T-L: trypsinlike; UPS: ubiquitin proteasome system.

\section{Competing interests}

The authors declare that they have no competing interests.

\section{Acknowledgements}

This research study was supported by: $\mathrm{NIH}$ grants CA 50947, CA 78373, CA100707-0I, a Doris Duke Distinguished Clinical Research Scientist Award (KCA), and The Cure for Myeloma Fund.

This article has been published as part of BMC Biochemistry Volume 9 Supplement I, 2008: Ubiquitin-Proteasome System in Disease Part 2. The full contents of the supplement are available online at http://www.biomedcen tral.com/I47|-209|/9?issue=SI.

Additional TPdb reviews on the ubiquitin-proteasome system are also available in BMC Biochemistry - see Volume 8 Suppl I http://www.biomedcen tral.com/|47|-209|/8? issue=SI.

\section{References}

I. Rock K, Gramm C, Rothstein L, Clark K, Stein R, Dick L, Hwang D, Goldberg A: Inhibitors of the proteasome block the degradation of most cell proteins and the generation of peptides presented on MHC class I molecules. Cell I994, 78:76I-77I.

2. Goldberg AL: Protein degradation and protection against misfolded or damaged proteins. Nature 2003, 426:895-899.

3. Adams J: The proteasome: a suitable antineoplastic target. Nat Rev Cancer 2004, 4:349-360.

4. Ciechanover A, Elias S, Heller H, Ferber S, Hershko A: Characterization of the heat-stable polypeptide of the ATP-dependent proteolytic system from reticulocytes. J Biol Chem 1980, 255:7525-7528.

5. Ciechanover A, Heller H, Elias S, Haas A, Hershko A: ATP-dependent conjugation of reticulocyte proteins with the polypeptide required for protein degradation. Proc Natl Acad Sci USA 1980 , 77:1365-1368.

6. Hershko A, Ciechanover A, Rose I: Resolution of the ATPdependent proteolytic system from reticulocytes: a component that interacts with ATP. Proc Natl Acad Sci USA 1979, 76:3107-31 10.

7. Hershko A, Ciechanover A, Heller H, Haas A, Rose I: Proposed role of ATP in protein breakdown: conjugation of protein with multiple chains of the polypeptide of ATP-dependent proteolysis. Proc Natl Acad Sci USA 1980, 77: I783-I786.

8. Ciechanover A, Finley D, Varshavsky A: Ubiquitin dependence of selective protein degradation demonstrated in the mammalian cell cycle mutant ts85. Cell 1984, 37:57-66.

9. Hershko A, Eytan E, Ciechanover A, Haas A: Immunochemical analysis of the turnover of ubiquitin-protein conjugates in intact cells. Relationship to the breakdown of abnormal proteins. J Biol Chem 1982, 257:13964-I3970.

10. Mukhopadhyay D, Riezman H: Proteasome-independent functions of ubiquitin in endocytosis and signaling. Science 2007, 3 15:201-205.

II. Wilk S, Orlowski M: Evidence that pituitary cation-sensitive neutral endopeptidase is a multicatalytic protease complex. J Neurochem 1983, 40:842-849.

12. Eytan E, Ganoth D, Armon T, Hershko A: ATP-dependent incorporation of $20 S$ protease into the 265 complex that degrades proteins conjugated to ubiquitin. Proc Natl Acad Sci USA 1989, 86:775 I-7755.

13. Hough R, Pratt G, Rechsteiner M: Purification of two high molecular weight proteases from rabbit reticulocyte lysate. J Biol Chem 1987, 262:8303-83I3.

14. Waxman L, Fagan JM, Goldberg AL: Demonstration of two distinct high molecular weight proteases in rabbit reticulocytes, one of which degrades ubiquitin conjugates. J Biol Chem 1987, 262:245।-2457.

I5. Driscoll J, Goldberg AL: The proteasome (multicatalytic protease) is a component of the $1500-\mathrm{kDa}$ proteolytic complex which degrades ubiquitin-conjugated proteins. J Biol Chem 1990, 265:4789-4792.

16. Ganoth D, Leshinsky E, Eytan E, Hershko A: A multicomponent system that degrades proteins conjugated to ubiquitin. Resolution of factors and evidence for ATP-dependent complex formation. J Biol Chem 1988, 263: I24I2-12419.

17. Arrigo A, Tanaka K, Goldberg A, Welch W: Identity of the I9S 'prosome' particle with the large multifunctional protease complex of mammalian cells (the proteasome). Nature 1988 , 331 : 192-194.

18. Peters JM, Cejka Z, Harris JR, Kleinschmidt JA, Baumeister W: Structural features of the $26 \mathrm{~S}$ proteasome complex. J Mol Biol I 993, 234:932-937.

19. Gray C, Slaughter C, DeMartino G: PA28 activator protein forms regulatory caps on proteasome stacked rings. J Mol Biol 1994, 236:7-I5.

20. Hershko A, Heller H, Elias S, Ciechanover A: Components of ubiquitin-protein ligase system. Resolution, affinity purification, and role in protein breakdown. J Biol Chem I983, 258:8206-82 I4.

21. Wilkinson K, Urban M, Haas A: Ubiquitin is the ATP-dependent proteolysis factor I of rabbit reticulocytes. J Biol Chem 1980, 255:7529-7532.

22. Hough R, Pratt G, Rechsteiner M: Ubiquitin-lysozyme conjugates. Identification and characterization of an ATP-depend- 
ent protease from rabbit reticulocyte lysates. J Biol Chem I986, 26 I:2400-2408

23. Swaminathan S, Amerik A, Hochstrasser M: The Doa4 deubiquitinating enzyme is required for ubiquitin homeostasis in yeast. Mol Biol Cell 1999, 10:2583-2594.

24. Pickart C: Targeting of substrates to the $26 \mathrm{~S}$ proteasome. Faseb J 1997, I I: 1055-1066.

25. Hershko $A:$ The ubiquitin system for protein degradation and some of its roles in the control of the cell division cycle. Cell Death Differ 2005, I 2: 1 191-1197.

26. Arendt $C$, Hochstrasser M: Identification of the yeast $20 \mathrm{~S}$ proteasome catalytic centers and subunit interactions required for active-site formation. Proc Natl Acad Sci USA 1997, 94:7|56-7|6|

27. Heinemeyer $W$, Fischer M, Krimmer T, Stachon U, Wolf D: The active sites of the eukaryotic $20 \mathrm{~S}$ proteasome and their involvement in subunit precursor processing. J Biol Chem 1997, 272:25200-25209.

28. Kisselev A, Goldberg A: Proteasome inhibitors: from research tools to drug candidates. Chem Biol 200I, 8:739-758.

29. Glotzer M, Murray A, Kirschner M: Cyclin is degraded by the ubiquitin pathway. Nature 1991, 349:132-138.

30. Pagano M, Tam S, Theodoras A, Beer-Romero P, Del SG, Chau V, Yew P, Draetta G, Rolfe M: Role of the ubiquitin-proteasome pathway in regulating abundance of the cyclin-dependent kinase inhibitor p27. Science 1995, 269:682-685.

31. Zhao J, Tenev T, Martins L, Downward J, Lemoine N: The ubiquitinproteasome pathway regulates survivin degradation in a cell cycle-dependent manner. J Cell Sci 2000, I I 3(Pt 23):4363-437I.

32. Finley D, Sadis S, Monia B, Boucher P, Ecker D, Crooke S, Chau V: Inhibition of proteolysis and cell cycle progression in a multiubiquitination-deficient yeast mutant. Mol Cell Biol 1994, I 4:550I-5509.

33. Adams J, Palombella VJ, Sausville EA, Johnson J, Destree A, Lazarus DD, Maas J, Pien CS, Prakash S, Elliott PJ: Proteasome inhibitors: a novel class of potent and effective antitumor agents. Cancer Res 1999, 59:2615-2622.

34. Dantuma N, Lindsten K, Glas R, Jellne M, Masucci M: Short-lived green fluorescent proteins for quantifying ubiquitin/proteasome-dependent proteolysis in living cells. Nat Biotechnol 2000, 1 8:538-543

35. Hideshima T, Richardson P, Chauhan D, Palombella V, Elliott $P$, Adams J, Anderson K: The proteasome inhibitor PS-34I inhibits growth, induces apoptosis, and overcomes drug resistance in human multiple myeloma cells. Cancer Res 200I, 6 I:307|-3076

36. Chauhan D, Catley L, Li G, Podar K, Hideshima T, Velankar M, Mitsiades C, Mitsiades N, Yasui H, Letai A, Ovaa H, Berkers C, Nicholson B, Chao TH, Neuteboom ST, Richardson P, Palladino MA, Anderson KC: A novel orally active proteasome inhibitor induces apoptosis in multiple myeloma cells with mechanisms distinct from Bortezomib. Cancer Cell 2005, 8:407-4I9.

37. Masdehors P, Omura S, Merle-Beral H, Mentz F, Cosset JM, Dumont J, Magdelenat H, Delic J: Increased sensitivity of CLL-derived lymphocytes to apoptotic death activation by the proteasome-specific inhibitor lactacystin. $\mathrm{Br} /$ Haematol 1999, 105:752-757.

38. Drexler HC, Risau W, Konerding MA: Inhibition of proteasome function induces programmed cell death in proliferating endothelial cells. Faseb J 2000, I 4:65-77.

39. Kudo Y, Takata T, Ogawa I, Kaneda T, Sato S, Takekoshi T, Zhao M, Miyauchi M, Nikai H: p27KipI accumulation by inhibition of proteasome function induces apoptosis in oral squamous cell carcinoma cells. Clin Cancer Res 2000, 6:916-923.

40. Bogner C, Schneller F, Hipp S, Ringshausen I, Peschel C, Decker T: Cycling B-CLL cells are highly susceptible to inhibition of the proteasome: involvement of p27, early D-type cyclins, Bax, and caspase-dependent and -independent pathways. Exp Hematol 2003, 31:218-225.

4I. Adams J, Kauffman M: Development of the proteasome inhibitor Velcade (Bortezomib). Cancer Invest 2004, 22:304-3II.

42. Karin M, Yamamoto Y, Wang QM: The IKK NF-kappa B system: a treasure trove for drug development. Nat Rev Drug Discov 2004, 3:17-26.

43. Haefner B: NF-kappa B: arresting a major culprit in cancer. Drug Discov Today 2002, 7:653-663.
44. Van WC: Nuclear factor-kappaB in development, prevention, and therapy of cancer. Clin Cancer Res 2007, I3:1076-1082.

45. Palombella V, Rando O, Goldberg A, Maniatis T: The ubiquitin-proteasome pathway is required for processing the NF-kappa B I precursor protein and the activation of NF-kappa B. Cell 1994, 78:773-785.

46. Jensen TJ, Loo MA, Pind S, Williams DB, Goldberg AL, Riordan JR: Multiple proteolytic systems, including the proteasome, contribute to CFTR processing. Cell I995, 83:| 29-135.

47. Chauhan D, Uchiyama H, Urashima M, Yamamoto K, Anderson KC: Regulation of interleukin 6 in multiple myeloma and bone marrow stromal cells. Stem Cells 1995, 2:35-39.

48. Chauhan D, Uchiyama H, Akbarali Y, Urashima M, Yamamoto $K$, Libermann T, Anderson K: Multiple myeloma cell adhesioninduced interleukin-6 expression in bone marrow stromal cells involves activation of NF-kappa B. Blood 1996, 87: II04-III2.

49. $\mathrm{Ni} \mathrm{H}$, Ergin M, Huang Q, Qin JZ, Amin HM, Martinez RL, Saeed S, Barton K, Alkan S: Analysis of expression of nuclear factor kappa B (NF-kappa B) in multiple myeloma: downregulation of NF. kappa B induces apoptosis. Br J Haematol 200 I, I I 5:279-286.

50. Hideshima T, Chauhan D, Richardson P, Mitsiades C, Mitsiades N, Hayashi T, Munshi N, Dang L, Castro A, Palombella V, Adams J, Anderson KC: NF-kappa B as a therapeutic target in multiple myeloma. J Biol Chem 2002, 277:16639-16647.

5I. Mitsiades N, Mitsiades CS, Poulaki V, Chauhan D, Richardson PG, Hideshima T, Munshi N, Treon SP, Anderson KC: Biologic sequelae of nuclear factor-kappaB blockade in multiple myeloma: therapeutic applications. Blood 2002, 99:4079-4086.

52. Landowski TH, Olashaw NE, Agrawal D, Dalton WS: Cell adhesionmediated drug resistance (CAM-DR) is associated with activation of NF-kappa B (RelB/p50) in myeloma cells. Oncogene 2003, 22:2417-242I.

53. Bharti A, Shishodia S, Reuben J, Weber D, Alexanian R, Raj-Vadhan S, Estrov Z, Talpaz M, Aggarwal B: Nuclear factor-kappaB and STAT3 are constitutively active in CDI38+ cells derived from multiple myeloma patients, and suppression of these transcription factors leads to apoptosis. Blood 2004, 103:3175-3184

54. Kane RC, Bross PF, Farrell AT, Pazdur R: Velcade: U.S. FDA approval for the treatment of multiple myeloma progressing on prior therapy. Oncologist 2003, 8:508-5/3.

55. LeBlanc R, Catley LP, Hideshima T, Lentzsch S, Mitsiades CS, Mitsiades N, Neuberg D, Goloubeva O, Pien CS, Adams J, Gupta D, Richardson PG, Munshi NC, Anderson KC: Proteasome inhibitor PS. $34 \mathrm{I}$ inhibits human myeloma cell growth in vivo and prolongs survival in a murine model. Cancer Res 2002 , 62:4996-5000.

56. Mitsiades CS, Mitsiades NS, Bronson RT, Chauhan D, Munshi N, Treon SP, Maxwell CA, Pilarski L, Hideshima T, Hoffman RM, Anderson KC: Fluorescence imaging of multiple myeloma cells in a clinically relevant SCID/NOD in vivo model: biologic and clinical implications. Cancer Res 2003, 63:6689-6696.

57. Tassone P, Neri P, Carrasco D, Burger R, Goldmacher V, Fram R, Munshi V, Shammas M, Catley L, Jacob G, Venuta S, Anderson K, Munshi $\mathrm{N}$ : A clinically relevant SCID-hu in vivo model of human multiple myeloma. Blood 2005, 106:7| 3-7/6.

58. Urashima M, Chen BP, Chen S, Pinkus GS, Bronson RT, Dedera DA, Hoshi Y, Teoh G, Ogata A, Treon SP, Chauhan D, Anderson KC: The development of a model for the homing of multiple myeloma cells to human bone marrow. Blood 1997, 90:754-765.

59. Uchiyama H, Barut B, Mohrbacher A, Chauhan D, Anderson K Adhesion of human myeloma-derived cell lines to bone marrow stromal cells stimulates interleukin-6 secretion. Blood 1993, 82:3712-3720.

60. Damiano J, Cress A, Hazlehurst L, Shtil A, Dalton W: Cell adhesion mediated drug resistance (CAM-DR): role of integrins and resistance to apoptosis in human myeloma cell lines. Blood 1999, 93:1658-1667.

6I. Neri P, Kumar S, Fulciniti MT, Vallet S, Chhetri S, Mukheriee S, Tai Y, Chauhan D, Tassone P, Venuta S, Munshi NC, Hideshima T, Anderson KC, Raje N: Neutralizing B-Cell Activating Factor Antibody Improves Survival and Inhibits Osteoclastogenesis in a Severe Combined Immunodeficient Human Multiple Myeloma Model. Clin Cancer Res 2007, I 3:5903-5909. 
62. Kisselev A, Goldberg A: Monitoring activity and inhibition of 26S proteasomes with fluorogenic peptide substrates. Methods Enzymol 2005, 398:364-378.

63. Lightcap E, McCormack T, Pien C, Chau V, Adams J, Elliott P: Proteasome inhibition measurements: clinical application. Clin Chem 2000, 46:673-683.

64. Berkers C, Verdoes M, Lichtman E, Fiebiger E, Kessler B, Anderson $K$, Ploegh $H$, Ovaa $H$, Galardy P: Activity probe for in vivo profiling of the specificity of proteasome inhibitor bortezomib. Nat Methods 2005, 2:357-362.

65. Kraus M, Ruckrich T, Reich M, Gogel J, Beck A, Kammer W, Berkers C, Burg D, Overkleeft $\mathrm{H}$, Ovaa $\mathrm{H}$, Driessen C: Activity patterns of proteasome subunits reflect bortezomib sensitivity of hematologic malignancies and are variable in primary human leukemia cells. Leukemia 2007, 2 I:84-92.

66. Orlowski R, Stinchcombe T, Mitchell B, Shea T, Baldwin A, Stahl S, Adams J, Esseltine D, Elliott P, Pien C, Guerciolini R, Anderson J, Depcik-Smith N, Bhagat R, Lehman M, Novick S, O'Connor O, Soignet S: Phase I trial of the proteasome inhibitor PS-34I in patients with refractory hematologic malignancies. J Clin Oncol 2002, 20:4420-4427.

67. Richardson PG, Barlogie B, Berenson J, Singhal S, Jagannath S, Irwin D, Rajkumar SV, Srkalovic G, Alsina M, Alexanian R, Siegel D, Orlowski RZ, Kuter D, Limentani SA, Lee S, Hideshima T, Esseltine DL, Kauffman M, Adams J, Schenkein DP, Anderson KC: A phase 2 study of bortezomib in relapsed, refractory myeloma. $N$ Engl J Med 2003, 348:2609-2617.

68. Richardson PG, Sonneveld P, Schuster MW, Irwin D, Stadtmauer EA, Facon T, Harousseau JL, Ben-Yehuda D, Lonial S, Goldschmidt H, Reece D, San-Miguel JF, Blade J, Boccadoro M, Cavenagh J, Dalton WS, Boral AL, Esseltine DL, Porter JB, Schenkein D, Anderson KC: Bortezomib or high-dose dexamethasone for relapsed multiple myeloma. N Engl J Med 2005, 352:2487-2498.

69. Richardson PG, Barlogie B, Berenson J, Singhal S, Jagannath S, Irwin D, Rajkumar SV, Hideshima T, Xiao H, Esseltine D, Schenkein D, Anderson KC: Clinical factors predictive of outcome with bortezomib in patients with relapsed, refractory multiple myeloma. Blood 2005, 106:2977-298I.

70. Richardson $P$, Sonneveld $P$, Schuster M, Irwin D, Stadtmauer E, Facon T, Harousseau J, Ben-Yehuda D, Lonial S, Goldschmidt H, Reece D, San MJ, Blade J, Boccadoro M, Cavenagh J, Alsina M, Rajkumar S, Lacy M, Jakubowiak A, Dalton W, Boral A, Esseltine D, Schenkein D, Anderson K: Extended follow-up of a phase 3 trial in relapsed multiple myeloma: final time-to-event results of the APEX trial. Blood 2007, I 1 0:3557-60.

7I. Lonial S, Waller EK, Richardson PG, Jagannath S, Orlowski RZ, Giver $C R$, Jaye DL, Francis D, Giusti S, Torre C, Barlogie B, Berenson JR, Singhal S, Schenkein DP, Esseltine DL, Anderson J, Xiao H, Heffner LT, Anderson KC: Risk factors and kinetics of thrombocytopenia associated with bortezomib for relapsed, refractory multiple myeloma. Blood 2005, 106:3777-3784.

72. O'Connor OA, Wright J, Moskowitz C, Muzzy J, MacGregor-Cortelli B, Stubblefield M, Straus D, Portlock C, Hamlin P, Choi E, Dumetrescu O, Esseltine D, Trehu E, Adams J, Schenkein D, Zelenetz AD: Phase II clinical experience with the novel proteasome inhibitor bortezomib in patients with indolent non-Hodgkin's lymphoma and mantle cell lymphoma. J Clin Oncol 2005, 23:676-684

73. Mitsiades N, Mitsiades CS, Poulaki V, Chauhan D, Fanourakis G, Gu X, Bailey C, Joseph M, Libermann TA, Treon SP, Munshi NC, Richardson PG, Hideshima T, Anderson KC: Molecular sequelae of proteasome inhibition in human multiple myeloma cells. Proc Natl Acad Sci USA 2002, 99:|4374-|4379.

74. Chauhan D, Li G, Shringarpure R, Podar K, Ohtake Y, Hideshima T, Anderson K: Blockade of Hsp27 overcomes Bortezomib/proteasome inhibitor PS-34I resistance in lymphoma cells. Cancer Res 2003, 63:6174-6177.

75. Chauhan D, Li G, Hideshima T, Podar K, Mitsiades C, Mitsiades N, Munshi N, Kharbanda S, Anderson KC: JNK-dependent release of mitochondrial protein, Smac, during apoptosis in multiple myeloma (MM) cells. J Biol Chem 2003, 278: I7593-I7596.

76. Hideshima T, Mitsiades C, Akiyama M, Hayashi T, Chauhan D, Richardson P, Schlossman R, Podar K, Munshi NC, Mitsiades N, Anderson $\mathrm{KC}$ : Molecular mechanisms mediating antimyeloma activity of proteasome inhibitor PS-34I. Blood 2003, I0 I:I530-I534.
77. Chauhan D, Li G, Sattler M, Podar K, Mitsiades C, Mitsiades N, Munshi N, Hideshima T, Anderson KC: Superoxide-dependent and independent mitochondrial signaling during apoptosis in multiple myeloma cells. Oncogene 2003, 22:6296-6300.

78. Mitsiades N, Mitsiades CS, Richardson PG, Poulaki V, Tai YT, Chauhan D, Fanourakis G, Gu X, Bailey C, Joseph M, Libermann TA, Schlossman R, Munshi NC, Hideshima T, Anderson KC: The proteasome inhibitor PS-34I potentiates sensitivity of multiple myeloma cells to conventional chemotherapeutic agents: therapeutic applications. Blood 2003, I 0 I:2377-2380.

79. Hideshima T, Mitsiades C, Tonon G, Richardson P, Anderson K: Understanding multiple myeloma pathogenesis in the bone marrow to identify new therapeutic targets. Nat Rev Cancer 2007, 7:585-598.

80. Obeng E, Carlson L, Gutman D, Harrington W Jr, Lee K, Boise L: Proteasome inhibitors induce a terminal unfolded protein response in multiple myeloma cells. Blood 2006, 1 07:4907-4916

81. Nawrocki ST, Carew JS, Dunner K Jr, Boise LH, Chiao PJ, Huang P, Abbruzzese JL, McConkey DJ: Bortezomib inhibits PKR-like endoplasmic reticulum (ER) kinase and induces apoptosis via ER stress in human pancreatic cancer cells. Cancer Res 2005, 65:11510-11519.

82. Chauhan D, Hideshima T, Anderson KC: Proteasome inhibition in multiple myeloma: therapeutic implication. Annu Rev Pharmacol Toxicol 2005, 45:465-476.

83. Joazeiro C, Anderson K, Hunter T: Proteasome inhibitor drugs on the rise. Cancer Res 2006, 66:7840-7842.

84. Mitsiades C, Mitsiades N, McMullan C, Poulaki V, Kung A, Davies F, Morgan G, Akiyama M, Shringarpure R, Munshi N, Richardson P, Hideshima T, Chauhan D, Gu X, Bailey C, Joseph M, Libermann T, Rosen N, Anderson K: Antimyeloma activity of heat shock protein-90 inhibition. Blood 2006, 107:1092-1100.

85. Chanan-Khan A, Richardson $P$, Alsina $M$, Carroll M, Lonial S, Krishnan A, Albitar M, Zhou Y, Mitsiades C, Cropp G, et al.: Phase I Clinical Trial of KOS-953 + Bortezomib (BZ) in Relapsed Refractory Multiple Myeloma (MM) [abstract]. Blood 2005, I 06:362.

86. Hideshima T, Chauhan D, Ishitsuka K, Yasui H, Raje N, Kumar S, Podar K, Mitsiades C. Hideshima H, Bonham L, Munshi NC, Richardson PG, Singer JW, Anderson KC: Molecular characterization of PS-34I (bortezomib) resistance: implications for overcoming resistance using lysophosphatidic acid acyltransferase (LPAAT)-beta inhibitors. Oncogene 2005, 24:3 I 2 I-3I 29.

87. Hideshima T, Podar K, Chauhan D, Ishitsuka K, Mitsiades C, Tai YT, Hamasaki M, Raje N, Hideshima H, Schreiner G, Nguyen AN, Navas T, Munshi NC, Richardson PG, Higgins LS, Anderson KC: p38 MAPK inhibition enhances PS-34I (bortezomib)-induced cytotoxicity against multiple myeloma cells. Oncogene 2004 23:8766-8776.

88. Navas T, Nguyen A, Hideshima T, Reddy M, Ma J, Haghnazari E, Henson M, Stebbins E, Kerr I, O'Young G, Kapoun A, Chakravarty S, Mavunkel B, Perumattam J, Luedtke G, Dugar S, Medicherla S, Protter A, Schreiner G, Anderson K, Higgins L: Inhibition of p38alpha MAPK enhances proteasome inhibitor-induced apoptosis of myeloma cells by modulating $\mathrm{Hsp} 27, \mathrm{Bcl}-\mathrm{X}(\mathrm{L}), \mathrm{Mcl}-\mathrm{I}$ and p53 levels in vitro and inhibits tumor growth in vivo. Leukemia 2006, 20:1017-1027.

89. Hideshima T, Chauhan D, Shima Y, Raje N, Davies FE, Tai YT, Treon SP, Lin B, Schlossman RL, Richardson P, Muller G, Stirling DI, Anderson $\mathrm{KC}$ : Thalidomide and its analogs overcome drug resistance of human multiple myeloma cells to conventional therapy. Blood 2000, 96:2943-2950.

90. Chauhan D, Li G, Podar K, Hideshima T, Shringarpure R, Catley L, Mitsiades C, Munshi N, Tai YT, Suh N, Gribble GW, Honda T, Schlossman R, Richardson P, Sporn MB, Anderson KC: The bortezomib/proteasome inhibitor PS-34I and triterpenoid CDDO-Im induce synergistic anti-multiple myeloma (MM) activity and overcome bortezomib resistance. Blood 2004 , 103:3158-3166.

91. Barlogie B: Thalidomide and CC-50I3 in multiple myeloma: the University of Arkansas experience. Semin Hematol 2003, 40:33-38.

92. Orlowski RZ, Voorhees PM, Garcia RA, Hall MD, Kudrik FJ, Allred T, Johri AR, Jones PE, Ivanova A, Van Deventer HW, Gabriel DA, Shea TC, Mitchell BS, Adams J, Esseltine DL, Trehu EG, Green M, Lehman MJ, Natoli S, Collins JM, Lindley CM, Dees EC: Phase I trial of the 
proteasome inhibitor bortezomib and pegylated liposomal doxorubicin in patients with advanced hematologic malignancies. Blood 2005, 105:3058-3065.

93. Orlowski RZ, Nagler A, Sonneveld P, Blade J, Hajek R, Spencer A, San Miguel J, Robak T, Dmoszynska A, Horvath N, Spicka I, Sutherland HJ, Suvorov AN, Zhuang SH, Parekh T, Xiu L, Yuan Z, Rackoff W, Harousseau JL: Randomized phase III study of pegylated liposomal doxorubicin plus bortezomib compared with bortezomib alone in relapsed or refractory multiple myeloma: combination therapy improves time to progression. J Clin Oncol 2007, 25:3892-390I.

94. Kopito RR: Aggresomes, inclusion bodies and protein aggregation. Trends Cell Biol 2000, 10:524-530.

95. Hideshima T, Bradner JE, Wong J, Chauhan D, Richardson P, Schreiber SL, Anderson KC: Small-molecule inhibition of proteasome and aggresome function induces synergistic antitumor activity in multiple myeloma. Proc Natl Acad Sci USA 2005, 102:8567-8572.

96. Nawrocki ST, Carew JS, Pino MS, Highshaw RA, Andtbacka RH, Dunner K Jr, Pal A, Bornmann WG, Chiao PJ, Huang P, Xiong H, Abbruzzese JL, McConkey DJ: Aggresome disruption: a novel strategy to enhance bortezomib-induced apoptosis in pancreatic cancer cells. Cancer Res 2006, 66:3773-378I.

97. Catley L, Weisberg E, Kiziltepe T, Tai Y, Hideshima T, Neri P, Tassone $P$, Atadja $P$, Chauhan D, Munshi N, Anderson K: Aggresome induction by proteasome inhibitor bortezomib and alpha-tubulin hyperacetylation by tubulin deacetylase (TDAC) inhibitor LBH589 are synergistic in myeloma cells. Blood 2006, 1 08:344I-3449.

98. Safety Study of LBH589 When Given in Combination With Bortezomib in Adult Patients With Multiple Myeloma [http:/ /clinicaltrials.gov/ct2/show/ NCT00532389?term $=$ NCT00532389\&rank $=$ I]

99. Feling RH, Buchanan GO, Mincer TJ, Kauffman CA, Jensen PR, Fenical W: Salinosporamide A: a highly cytotoxic proteasome inhibitor from a novel microbial source, a marine bacterium of the new genus salinospora. Angew Chem Int Ed Engl 2003, 42:355-357.

100. Macherla V, Mitchell S, Manam R, Reed K, Chao T, Nicholson B, Deyanat-Yazdi G, Mai B, Jensen P, Fenical W, Neuteboom S, Lam K, Palladino M, Potts B: Structure-activity relationship studies of salinosporamide A (NPI-0052), a novel marine derived proteasome inhibitor. J Med Chem 2005, 48:3684-3687.

10I. Groll M, Huber R, Potts BC: Crystal structures of Salinosporamide $A$ (NPI-0052) and B (NPI-0047) in complex with the $20 \mathrm{~S}$ proteasome reveal important consequences of beta-lactone ring opening and a mechanism for irreversible binding. J Am Chem Soc 2006, I28:5 I36-5I4I.

102. Ruiz S, Krupnik Y, Keating M, Chandra J, Palladino M, McConkey D: The proteasome inhibitor NPI-0052 is a more effective inducer of apoptosis than bortezomib in lymphocytes from patients with chronic lymphocytic leukemia. Mol Cancer Ther 2006, 5:1836-1843.

103. Oberdorf J, Carlson EJ, Skach WR: Redundancy of mammalian proteasome beta subunit function during endoplasmic reticulum associated degradation. Biochemistry 200I, 40:13397-13405

104. Demo SD, Kirk CJ, Aujay MA, Buchholz TJ, Dajee M, Ho MN, Jiang J, Laidig G], Lewis ER, Parlati F, Shenk KD, Smyth MS, Sun CM, Vallone MK, Woo TM, Molineaux CJ, Bennett MK: Antitumor activity of PR-I7I, a novel irreversible inhibitor of the proteasome. Cancer Res 2007, 67:6383-6391.

105. Stapnes C, Doskeland AP, Hatfield K, Ersvaer E, Ryningen A, Lorens JB, Gjertsen BT, Bruserud O: The proteasome inhibitors bortezomib and PR-I7I have antiproliferative and proapoptotic effects on primary human acute myeloid leukaemia cells. $\mathrm{Br}$ J Haematol 2007, | 36:8|4-828.

106. Kuhn DJ, Chen Q, Voorhees PM, Strader JS, Shenk KD, Sun CM, Demo SD, Bennett MK, van Leeuwen FW, Chanan-Khan AA Orlowski RZ: Potent activity of carfilzomib, a novel, irreversible inhibitor of the ubiquitin-proteasome pathway, against preclinical models of multiple myeloma. Blood 2007, I I 0:328I-3290.

107. Safety Study of the Proteasome Inhibitor PR- 17 I in Patients With Hematological Malignancies [http://clinicaltrials.gov/ct2/ show/NCT00150462?term=NCT00I50462\&rank=I]
108. Phase 2 Study of Carfilzomib in Relapsed and Refractory Multiple Myeloma [http://clinicaltrials.gov/ct2/show/ NCT005 I | 238?term $=$ NCT005 I | 238\&rank $=1]$

109. Chauhan D, Hideshima T, Mitsiades C, Richardson P, Anderson KC: Proteasome inhibitor therapy in multiple myeloma. Mol Cancer Ther 2005, 4:686-692.

I 10. Cusack JC Jr, Liu R, Xia L, Chao TH, Pien C, Niu W, Palombella VJ, Neuteboom ST, Palladino MA: NPI-0052 enhances tumoricidal response to conventional cancer therapy in a colon cancer model. Clin Cancer Res 2006, I 2:6758-6764.

\section{Publication history}

Republished from Current BioData's Targeted Proteins database (TPdb; http://www.targetedproteinsdb.com).
Publish with BioMed Central and every scientist can read your work free of charge

"BioMed Central will be the most significant development for disseminating the results of biomedical research in our lifetime. "

Sir Paul Nurse, Cancer Research UK

Your research papers will be:

- available free of charge to the entire biomedical community

- peer reviewed and published immediately upon acceptance

- cited in PubMed and archived on PubMed Central

- yours - you keep the copyright
BioMedcentral 